\author{
Ewa Malchrowicz-Mośko \\ ORCID 0000-0002-7676-1477 \\ Maciej Młodzik \\ Department of Humanistic Foundations of Tourism and Recreation \\ Faculty of Tourism and Recreation \\ Poznan University of Physical Education \\ malchrowicz@awf.poznan.pl,maciej_mlodzik@wp.pl \\ Adrianna Banio \\ ORCID 0000-0001-5514-9177 \\ Department of Sport Theory and Practice \\ Faculty of Physical Culture and Health Promotion \\ University of Szczecin \\ adrianna.banio@wp.pl \\ Adam Omorczyk \\ Faculty of Social Sciences \\ University of Silesia in Katowice \\ adam.omorczyk@gmail.com
}

\title{
TRIATHLON AS A FORM OF SPORTS CONSUMPTION: MOTIVES FOR PARTICIPATION
}

\begin{abstract}
This article presents triathlon as a modern form of sports consumption. The theoretical part underlines the importance of triathlon events for the development of tourism and the promotion of health and physical activity, whereas the empirical part presents the results of research carried out at the Środa Wielkopolska Triathlon 2018 event. The socio-demographic profile of the participants of the event $(\mathrm{N}=109)$ and their motives for participation were determined. The information contained may be of value for those involved in the development of sport and tourism in smaller towns in Poland.
\end{abstract}

Keywords: triathlon, promotion of physical activity, sports tourism.

\section{INTRODUCTION}

Triathlon is a sport discipline consisting of swimming, running and cycling, merged into one 'combined race' that aims at not only making the competition difficult, but also making each discipline more attractive to potential spectators. The first triathlon took place in 1974 in the United States, and 10 years later in Poznań, Poland. As an Olympic discipline, triathlon appeared for the first time at the Olympic Games in Sydney in 2000. Although it is still not a popular discipline, it is gaining in popularity, as indicated in the later part in this article. Therefore, the main aim is to examine the phenomenon of triathlon and find out what the socio-demographic profile of its participants and motives for the participation of Poles in such events are. As this information is important for those involved in the organization of sports and tourism in cities, the article additionally investigates how the participation in a triathlon event affects the promotion of health and physical activity, by choosing the Środa Wielkopolska Triathlon 2018 as a case study.

In recent years, a dynamic increase in the importance of sport and recreation in the life of a postmodern human can be observed, as well as a growing interest in a healthy lifestyle, the result of the development of healthism in western societies (CRAWFORD 2006). This is a neologism coined by Robert Crawford in the early 1980s describing an interest (often excessive) in health and medicine especially popular in western societies (BOROWIEC \& LIGNOWSKA 2012). For the contemporary consumer of culture, sport and tourism, understood as lifestyle elements, become an important set of principles, rules and values. Through abiding and cultivating 
these principles, premises for multidimensional human development, both in physical and spiritual spheres can be created. Those who work on their bodies in free time experience dynamic transformations within physical and spiritual areas. In modern societies (especially western countries), those who declare themselves as active, develop an above average norm of human activity and creativity. Therefore, it is essential to substantively discuss the issue of sports tourism as a socio-cultural phenomenon which affects the natural, cultural and economic environment, and is conducive to the self-fulfilment of lifestyle as preferred today. Promotion of an active lifestyle is an important element of the social policy of many countries, with mass media, mass sports and recreational events dedicated to amateur athletes playing an important role in this process. These events have become an important element in the development of sports tourism - one of the fastest growing sectors of the tourism industry today. Moreover, they help cities and regions improve their image (marketing place). Therefore, it is important to study the motives for participation in sports events, both from the point of view of physical culture and health promotion, as well as in the context of tourism and the economic recovery of tourist regions.

\section{MASS SPORTS AND RECREATIONAL EVENTS - THE EFFECTS ON HEALTH PROMOTION AND TOURISM DEVELOPMENT - THEORETICAL REVIEW}

Leading an active lifestyle in Poland is becoming very popular, and is regarded by sociologists as a distinctive feature of the middle class (BOROWIEC \& LIGNOWSKA 2012; STEMPIEŃ 2016). Since the lack of physical activity is now considered one of the main factors in the development of many diseases of affluence: diabetes, obesity, hypertension, cardiovascular diseases, etc.; an active lifestyle can be considered a positive phenomenon. In turn, these diseases directly generate high financial costs for the state, i.e. health care and indirectly cause a reduction in production due to illness and a related incapacity for work or premature death (WARBURTON et al., 2006). Therefore, attempts are being made to make Polish society physically active. According to the World Health Organization, adults should do at least 150 minutes of moderate-intensity exercises, or at least 75 minutes of vigorous-intensity exercises per week (WHO). Academics and healthcare professionals have been looking for reasons why some people are physically active while others not. Motives for participating in physical activity are very complex, with motivation being a key factor in activating and maintaining such behaviour in individuals (AALTONEN et al. 2012).
Over recent years, the concept of healthism has been developing in Poland. The scale of this social trend is an extraordinary phenomenon at many levels with a number of factors being taken into account (including interdisciplinary ones). It appears that the physical activity of Poles in the last two decades has increased. Positive changes began to be noticed after the political transformations in Poland in 1989. Previously, Poles were a nation that, in contrast to Western societies, was characterized by much lower physical activity, nevertheless, social, cultural and economic factors led to an increase. Today, Poles are better educated, wealthier, have more free time, and move to cities with dynamically developed sports infrastructures: swimming pools, fitness clubs and cycle paths. Not so long ago, Poles worked mainly physically (e.g. on the land and in factories), and therefore did not think about taking up running or swimming. Today, these have changed in favour of intellectual work (e.g. in offices, remote work from home, etc.). Moreover, their way of spending free time allows them to emphasize their social status. Sport and sports tourism have become characteristic features of the middle class in Poland, with more and more people choosing running as their exercise of choice. In recent years, extreme and challenging forms of sports activity, such as triathlon, have also become more important and popular.

Nevertheless, Poles are still more akin to the less active inhabitants of southern European countries (including Greece) than the inhabitants of Scandinavian countries, where the vast majority of citizens are active (BIERNAT \& PIĄTKOWSKA 2012). One can also ironically state that 'Poles are triathlonists', as the favourite disciplines of Poles are running (33\% of the physically active), swimming (29\%) and cycling (53\%) (Aktywność fizyczna Polaków TNS Polska, 2015). On the other hand, a craze for a healthy and active lifestyle has been observed in Poland for a long time. Running events are organized even in small Polish towns. Among the physically active Poles, the manner of consumption and the chosen forms of physical activity are changing. In this respect, Poles are heading towards western patterns. Mass sport and participation in mass sports events are developing dynamically. Poles are more and more often becoming sports tourists. Participation in organized mass sports and recreational events has become an extremely attractive form of physical recreation. This can be first and foremost seen in the case of mass sports events such as marathons and half-marathons, which have a significant impact on the tourist revival of cities and regions. The turnout in such events in recent years has increased: Poznań Pótmaraton (by 800\% from 2008), Poznań Triatlon (by 300\% from 2013), Poznań Bike Challenge (by 40\% from 2014), Poznań Maraton (by 900\% from 2000) - (based on data from event organizers, September 2018). The number of organized events and 
participants have increased significantly since 2000 . Every year, the country hosts over 15 large marathons. This number includes only those in which participants are counted in thousands. Poznan is an example of a city with a very wide offer of sports events. Over 500 events at various levels are organized every year in the city and region of Wielkopolska which puts it in the forefront. This trend draws attention to the issue of the motivation of runners as, especially in the context of everyday life, both training and preparation for a sports event are somewhat of a luxury. Training is very exhaustive, and those engaged in triathlon have high requirements regarding physical exertion.

The promotion of health and physical activity is an important function of modern sports events. According to Eurobarometer, only $27 \%$ of citizens perform regular activities in Poland, which puts the country in one of the lowest positions in the EU. According to a CBOS report, the main motive for undertaking sport by Poles is health $(70 \%)$ followed by pleasure $(61 \%)$. Nearly every other person undertaking physical activity declares that they exercise to feel better, relieve stress, or be fit $(47 \%)$. The research conducted as part of Projekt Społeczny 2012 commissioned by the Ministry of Sport and Tourism, shows that there was observed a significant variation in the frequency of physical activity by the inhabitants of individual voivodeships (BIERNAT \& PIĄTKOWSKA 2012). Its results show that only in two voivodeships, Wielkopolskie and Dolnośląskie, was the share of active people (doing sport every day or often) exceeded the share of the inactive. The analytical report Ocena korzyści społecznych inwestycji w sport w odniesieniu do ponoszonych kosztów (Evaluation of the Social Benefits of Investment in Sport in Relation to the Costs Incurred) carried out in 2016 by the Ministry of Sport and Tourism shows that young people are much more often active than the elderly. The level of activity and intensity decreases with age. In the 15-24 age group, the percentage of those with the lowest level of physical activity is $38 \%$, whereas in the $55-64$ age group, it is $72 \%$; and $95 \%$ in the $75-84$ age group. On the other hand, the physically inactive are respectively $24 \%, 61 \%$ and $91 \%$ of respondents. Similarly, the percentage of those with the highest level of physical activity decreases with age. Among those aged 15-24, they constitute $39 \%$ of the population, while in the 55-64 age group, $12 \%$. In addition to age, another factor significantly differentiating the level of physical activity is education where it can be observed that the percentage of physically active in the group with higher education is higher and amounts to $53 \%$. The average time devoted to physical activity is 2 hours and 50 min weekly (BIERNAT \& PIĄTKOWSKA 2012). This data is confirmed by the CBOS report Aktywność Fizyczna Polaków (The Physical Activity of Poles) published by Małgorzata Omyła-Rudzka in 2013. However, it can be noticed that there is a differ- ence between the two reports in relation to the physical activity of women and men. According to the Ministry's report, the percentage of both sexes is the same. But as a result of the report published by CBOS, men take up physical activities more often than women do. In order to encourage as many social groups as possible to perform physical activity, many new sports disciplines are emerging, while those that already exist are subject to further diversification. Triathlons can be an example that puts high physical and mental demands on their participants. A triathlon can be treated as a modern form of sports consumption.

According to Aldridge, the concept of consumption relates to all goods and services (ALDRIDGE 2006). Its significance is shaped mainly by the transformation of modern production society into a post-modern consumer focused on a search for sensation and experience (SCHULZE 1992). These social changes coincide with the development of modern sport, and has caused its gradual integration into the mainstream of consumer culture. In its narrow definition, sports consumption may include the participation of fans in live sports events (direct consumption) or through the media (indirect consumption). However, in a broader sense, sports consumption should be treated as participation in sports and recreational services. Sport is a product for which demand is constantly growing and which satisfies many emotional needs. The direction of developmental change in contemporary sports and recreational activity is the transition from 'recreation to excitement'. The emergence of highly individualized and sometimes surprising social preferences in the selection of sports and recreational activities can be observed, more and more often characterized by a search for new, more exciting and extreme forms of expression (GRACZ, WALCZAK \& TOMCZAK 2011). The triathlon demonstrates such tendencies. Recent changes leading to an increased interest in a healthy lifestyle and physical activity; the emergence of new sport disciplines; as well as competition for participants, including sports tourists, increase the importance of research on the motives for participation in particular sports events that are supposed to be an incentive for the Polish society to carry out physical activity.

\section{MOTIVES FOR PARTICIPATION IN TRIATHLON: RESULTS OF EMPIRICAL RESEARCH}

The research carried out by means of a diagnostic poll method and a standardized interview technique was carried out among the 109 participants of the Środa Wielkopolska Triathlon event $(\mathrm{N}=109)$, which took place in September 2018. The picturesque Średzkie Lake with its full infrastructure, in the form of a marina and 
trails that surround the lake, provides perfect conditions for the race. In 2018, participants competed at distances of 1/8 $(28.25 \mathrm{~km}), 1 / 4(56.5 \mathrm{~km}), 1 / 4$ relay $(56.5 \mathrm{~km})$, and in joint races for children and adults (KIDS+ in the original form). The competitors had to overcome a very fast cycling route and a spectacular cross-country trail leading along the shore of the lake and the yacht marina. Thanks to the accessibility of the routes at all stages, supporters could easily follow the course of the competition in the beautiful scenery of Średzkie Lake.

The one eighth Iron Man Distance $(28.25$ km: $475 \mathrm{~m}$ swimming, $22.5 \mathrm{~km}$ cycling, $5.275 \mathrm{~km}$ running) - was completed by 109 participants. The distance of one quarter Iron Man (56.50 km: 950 m swimming, 45 km cycling, and $10.55 \mathrm{~km}$ running) by 134 participants. Whereas, the one quarter iron Man 3-man relay $(56.50 \mathrm{~km})$ for men, women and mixed groups, where each competitor participated in one discipline handing on a chip in the transition area, was finished by 32 relay teams. For the first time, this year's triathlon included TRIFAMILY - races with parent/guardian pairs, during which the pairs first had to cover a distance in a double tourist kayak, and then the child rode a bike, while a 'guard' was riding a stationary bike provided by the organizer. At the end, they had to cross the running distance together. 28 pairs took part in the race. Another new competition was KIDS - divided into four age categories, based on a duathlon, in which 69 participants took part:

- Category D (2005-2007 age groups) - cycling $2000 \mathrm{~m}$, running $800 \mathrm{~m}$

- Category C (2008-2009 age groups) - cycling $1000 \mathrm{~m}$, running $400 \mathrm{~m}$

- Category B (2010-2011 age groups) - cycling $500 \mathrm{~m}$, running $200 \mathrm{~m}$

- Category A (2012-2015 age groups) - cycling $200 \mathrm{~m}$, running $100 \mathrm{~m}$

Their socio-demographic profile: usually men (68\%) (Fig. 1); aged 18-25 (62\%) (Fig. 2); with higher education (59\%) (Fig. 3); professionally active (73\%) (Fig. 4); from a city of over 500000 (35\%) (Fig. 5). Thus, they were most often participants who came to Środa Wielkopolska, probably accompanied by their supporters. Therefore, the sports event had a positive effect on a tourism revival.

The respondents were asked about their strongest motives for participating in the Środa Wielkopolska Triathlon. A maximum of five responses could be selected for each group of motives, divided into four groups: social orientation (Fig. 6), psychological and emotional orientation (Fig. 7), orientation towards sport and competition (Fig. 8), and in physical and health orientation (Fig. 9). The results of the research were presented in order of motives.
Among the most common motives for participation in the triathlon were the desire to test oneself - $71 \%$ (desire to win or with the defeating opponents), the desire to maintain physical fitness (65\%), social needs - a desire to spend time with friends and maintain friendships (61\%) and a desire to have fun, relax and escape from everyday life $-60 \%$. Therefore, it turned out that participation, apart from needs related to care for health and physical fitness, also fulfils important

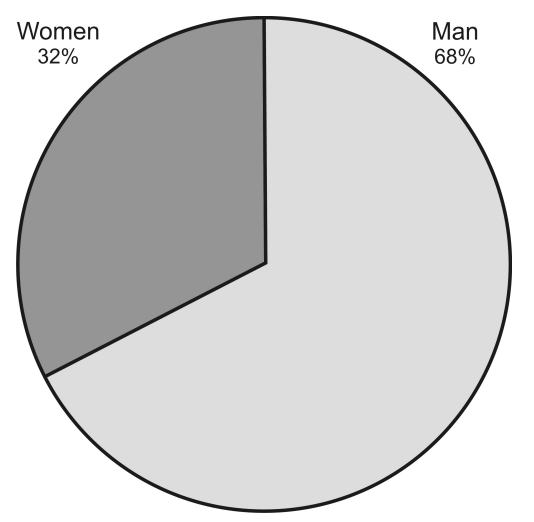

Fig. 1. Sex

Source for figs 1-9: authors

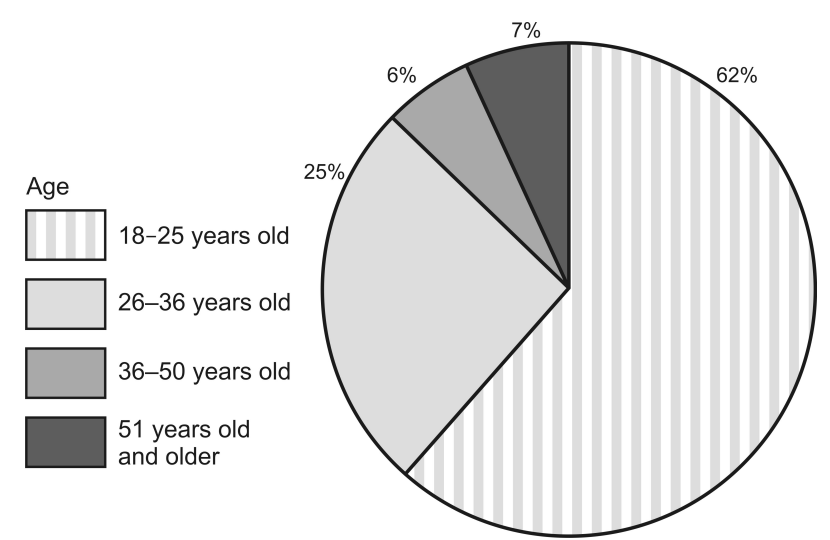

Fig. 2. Age

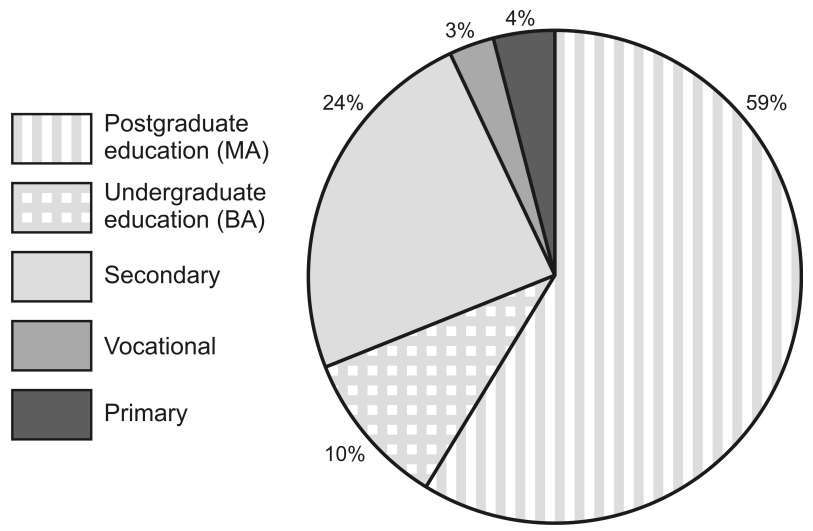

Fig. 3. Education 


\begin{tabular}{|c|c|}
\hline & $\begin{array}{l}\text { Professionally } \\
\text { active }\end{array}$ \\
\hline & Student \\
\hline & Pupil \\
\hline & Pensioner \\
\hline & Unemployed \\
\hline
\end{tabular}

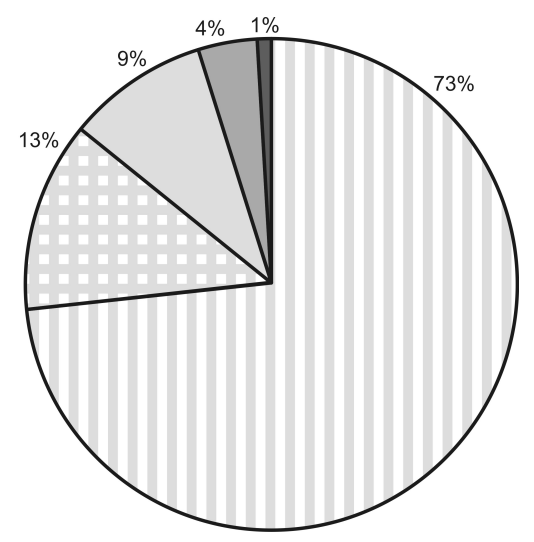

Fig. 4. Employment situation

Prevailing trend - participation in sports events now popular

Desire to gain recognition in the eyes of others

Need to make new friends

Belonging to sports subculture

Need to do something and stand out from the crowd

Desire to feel united and integrated with other people who share my interested

Liking to practice with other people and sharing with them the job of winning or losing

Desire to spend time with friends maintain friendships

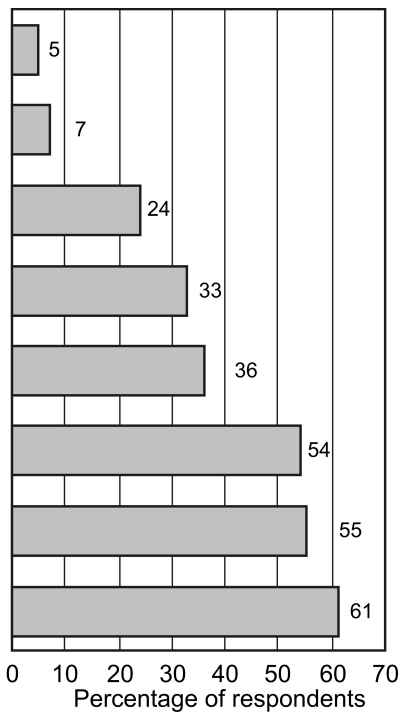

Fig. 6. Motives regarding social relations

High rank of the sports events

Desire to win

Desire to participate in sports competition with others

Desire to achieve a set goal

Desire to acquired new / maintain old skills

Desire to increase the level of previously acquired skills,

develop passion - I want to be better at what I am doing

Liking challenges and disciplines that are demanding

Desire to test one self

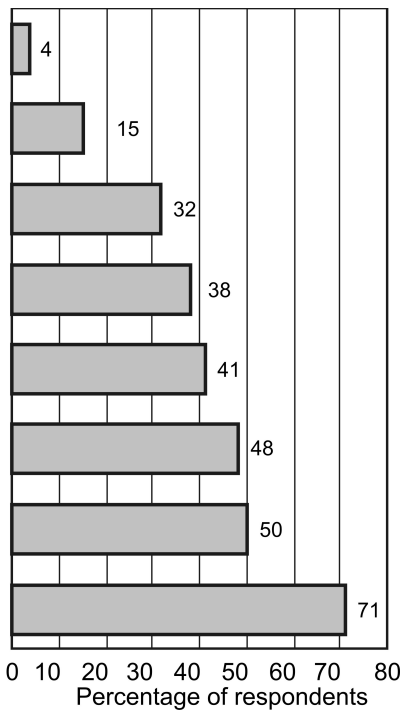

Figure 8. Motives related to competence and competition

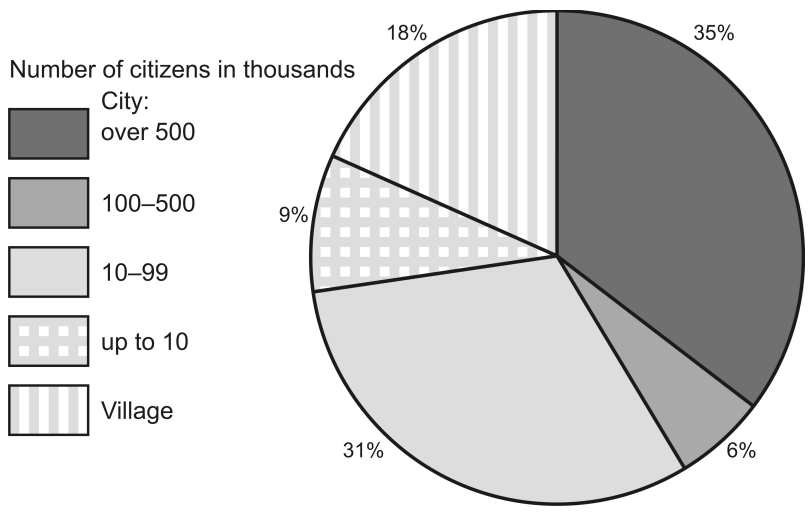

Fig. 5. Place of residence

Because this activity is stimulating

Desire to break away from everyday life

Because this activity makes me happy

Enjoying this form of spending time

Desire to experience strong emotion and experiences associated with the participation

Because this form of spending time in interesting

Liking physical activity related to this sport discipline

Desire to have fun, relax and relieve stress

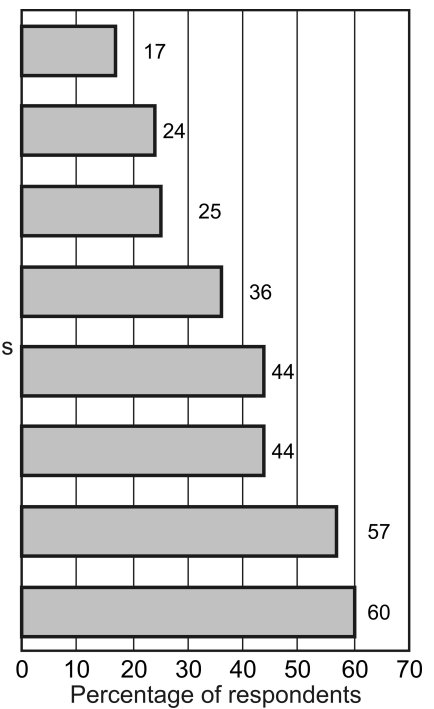

Fig. 7. Motives regarding feelings and emotions

Feeling physically unattractive if not doing it

Desire to be attractive

Desire to lead a healthy life style

Desire to have and maintain / improve the body shape, weight, muscle and good appearance

Desire to have more energy

Desire to be healthy, take care of the cardiovascular system

Desire to feel good physically and mentally

Desire to maintain good physical condition

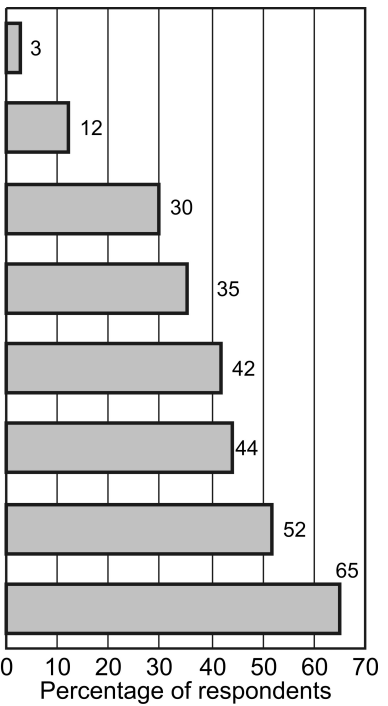

Figure 9. Motives related to physical fitness, health and appearance 
social functions - fostering contacts and social relations. This may be due to the fact that modern culture is dominated by individualism and does not offer many opportunities for collective behaviour, while sports events create an opportunity to feel part of a larger community. However, the most important motivation was the desire to test oneself, which is in line with contemporary trends observed in sport, where participants go from recreation to excitement and set higher and higher goals in the field of physical culture.

The respondents were also asked if they planned to participate in the next Środa Wielkopolska Triathlon event. The answers were optimistic for the event organizers and the development of sports tourism. $41 \%$ decided that they would definitely take part in the event once again, $34 \%$ that there is a high probability, $18 \%$ 'maybe', 5\% 'probably not', and 1\% that they would not.

Furthermore, it was investigated to what extent participation in the Środa Wielkopolska Triathlon event encouraged respondents to continue an active lifestyle (according to the World Health Organization, an active lifestyle is understood as exercising for at least $150 \mathrm{~min}$ utes per week [moderate-intensity] or at least 75 minutes per week [vigorous-intensity]). A 7-point Likert scale was used (Table 1). The average was at a high level - 5.17 points. This is a positive result from the point of view of promoting health and physical activity.

Table 1. The level of willingness to continue an active lifestyle based on the scale 1-7

\begin{tabular}{|c|c|c|c|c|c|c|c|}
\hline Scale & 1 & 2 & 3 & 4 & 5 & 6 & 7 \\
\hline $\begin{array}{c}\text { Number } \\
\text { of respondents }\end{array}$ & 3 & 3 & 8 & 16 & 25 & 36 & 18 \\
\hline
\end{tabular}

Key: 1 - little interest, 7 - very strong interest. Source: authors.

\section{SUMMARY}

The recent observed change in trends leading to an increase in interest in a healthy lifestyle and physical activity, the popularity of new sport disciplines and competition for participants (including tourists), and an increase in the importance of research on the current way of perceiving a given discipline as a way to encourage society to do physical activity. Changes taking place in tourism, and socio-cultural changes in countries with a highly developed economy, especially in terms of their value system and lifestyle, have a significant impact on the nature of needs and motivation for travel. The increase in wealth and leisure time resources means that more and more people can travel, explore the world on their own, and develop their interests, including those related to sport. Tourists em- bark on a journey to explore, break away from everyday life, experience 'something special' and, above all, to 'experience'. These needs are now met by sports tourism - currently one of the fastest growing sectors of the tourism industry. Attitudes to sensations and experiences resulting from a wish for a healthy lifestyle and showing off a 'fit' body significantly affect interest in this type of tourism. Another important function of sports events is building a sense of community among those with similar views and lifestyles. Not only is the offer of active ways of spending free time expanding, but so are free-time activities. As a result, many new forms of active tourism and modern physical activity are created, together with modifications of 'classical' sport disciplines. This article presents the socio-demographic profile of a participant in a modern form of sports consumption, the triathlon. The main motives for participation were also investigated.

The aim of this article was therefore achieved, as both the demographic of triathlon participants and, most importantly, motives for participation were presented. The results indicated are optimistic. When asked if participants wanted to take part in the next Środa Wielkopolska competition, only $6 \%$ of answers were negative, while the rest confirmed with greater or lesser probability their willingness to participate again. These results justify that, in the context of the promotion of tourism and physical culture, it is worth organizing mass sports and recreational events in small towns such as Środa Wielkopolska, as such places do not have many opportunities to emphasize their importance on the tourist map of Poland. Furthermore, these events can have a positive impact on the perception of physical culture among residents. Therefore, it appears to be justified to say that sports tourism is becoming a driving force for social growth and economic development. By 2020, it is expected that there will be a $5 \%$ increase in sports tourism income annually (WEED 2008). Therefore, big sports events, such as the triathlon presented in the article, can diversify a tourism product and affect its innovativeness. It is reasonable to say undergo transformation along with cultural, social, economic and technological changes. They are multidimensional and diverse, making them attractive to a potential consumer who, depending on motivation, awareness and attitude, becomes a participant and co-creator of sports tourism.

\section{BIBLIOGRAPHY}

AALTONEN S. i in., 2012, Motives for and barriers to physical activity in twin pairs discordant for leisure time physical activity for 30 years, International Journal of Sports Medicine, 33, 1 , pp. $157-163$. 
ALDRIDGE A., 2006, Konsumpcja, Key Concepts, Warszawa.

BIERNAT E., PIĄTKOWSKA M., 2012, Rekreacyjna aktywność fizyczna Polaków na tle Europy. Raport dla Departamentu Analiz i Polityki Sportowej, Ministerstwo Sportu i Turystyki, Warszawa.

BOROWIEC A., LIGNOWSKA I., 2012, Is the ideology of healthism a distinctive feature of the middle class in Poland?, Culture and Society - Sport in Culture, 56, 3, pp. 95-111.

CRAWFORD R., 2006, Health as a meaningful social practice, Health: An Interdisciplinary Journal for the Social Study of Health, Illness and Medicine, 10, 4, pp. 401-420.

Ministerstwo Sportu i Turystyki, 2016, Ocena korzyści społecznych inwestycji w sport w odniesieniu do ponoszonych kosztów. Raport analityczny, Ministerstwo Sportu i Turystyki, Warszawa.

OMYŁA-RudZKA M., 2013, Aktywność fizyczna Polaków, Centrum Badania Opinii Społecznej, Warszawa.

SCHUlZE G., 1992, Die Erlebniz-Gesellschaft. Kultursoziologie der Gegenwart, Campus-Verlag, Frankfurt am Main.

STEMPIEŃ J., 2016, Bieganie, zwiedzanie i klasa średnia - przygarść socjologicznych uwag i obserwacji o turystyce biego- wej, [in:] M. Kazimierczak (ed.), Inspiracje sportem w turystyce kulturowej, Akademia Wychowania Fizycznego w Poznaniu, Poznań, pp. 48-59.

WARbuRTON D.E., NICOL C.W., BREDIN S.S., 2006, Health benefits of physical activity: the evidence, Canadian Medical Association Journal, 174 , 6, pp. 801-809.

WALCZAK M., GRACZ J., TOMCZAK M., 2011, Poszukiwanie doznań jako tendencja we współczesnej aktywności sportowo-rekreacyjnej, [in:] P. Niedzielski, J. Witek (ed.), Sport i rekreacja a wyzwania wspótczesnej cywilizacji, Uniwersytet Szczeciński, Szczecin, pp. 47-65.

WEED M., 2008, Sports tourism experience, Journal of Sport and Tourism, 13, 1, pp. 1-4.

WHO, www.who.int.

Artykuł wpłynął: 24 września $2018 \mathrm{r}$. Zaakceptowano do druku: 4 listopada $2018 \mathrm{r}$. 
